GORAN ANTONIĆ, istraživač-saradnik

Institut za savremenu istoriju

Beograd, Trg Nikole Pašića 11

UDK 711.4(497.11)"1918/1934"(093.2)

\title{
PODRUČJE NOVOG BEOGRADA U MEĐURATNIM PLANOVIMA ZA RAZVOJ ZEMUNA 1918-1934. ${ }^{*}$
}

\begin{abstract}
APSTRAKT: Članak je posvećen međuratnim planovima za širenje Zemuna na prostor leve obale Save, gde je kasnije izgrađen Novi Beograd. U njemu se ispituje poreklo tih planova, koje seže do austrougarskog vremena, kao i tok njihovog razvoja, sve do ukidanja samostalnosti zemunske opštine i njenog pripajanja Beogradu 1934. Budući da je u literaturi ova tema vrlo malo obrađena, na njen značaj posebno ukazuje činjenica da je u zemunskoj upravi nastao ne samo najstariji dosad poznati koncept uređenja područja leve Save, već i da je ova uprava početkom tridesetih godina izradila jedini regulacioni plan koji je bio zvaničan predlog izgradnje tog prostora tokom međuratnog perioda.
\end{abstract}

Ključne reči: Zemun, Novi Beograd, međuratno razdoblje, urbanističko planiranje, Đorđe Kovaljevski

Novi Beograd je moderan deo Beograda čija je izgradnja počela neposredno posle Drugog svetskog rata (1947). U odnosu na staro jezgro grada, on je podignut na prostoru suprotne - leve, obale Save, na mestu gde se ta reka uliva u Dunav. Iako formiran kao potpuno nova urbana struktura, Novi Beograd je svoje ishodište imao u idejnom i materijalnom nasleđu iz prethodnog vremena. Još u doba međuratne Jugoslavije nastali su ne samo prvi planovi za integraciju prostora leve obale Save u sastav Beograda već je, u rudimentarnom obliku, započeta i realizacija te ideje. To je obuhvatalo izradu prvih javnih i infrastrukturnih objekata, kao i nasipanje terena sa idejom urbane izgradnje. Pored toga, tada je nastalo i jedno veće, neplanski podignuto naselje čiji je naziv - „Novi Beograd“, anticipirao ime budućeg dela grada. S izbijanjem Drugog svetskog rata, početak urbanog razvoja

* Rad je deo projekta Srpsko društvo u jugoslovenskoj državi u 20. veku: između demokratije i diktature (177016), koji finansira Ministarstvo prosvete, nauke i tehnološkog razvoja Republike Srbije. 
prostora leve obale Save naglo je prekinut, upravo kada je trebalo da se intenzivira. ${ }^{1}$

Tek u najskorije vreme postalo je poznato da su uporedo s međuratnim idejama za širenje Beograda na to područje postojale i ideje za razvoj susednog Zemuna na isti teren. ${ }^{2}$ Budući da je pre svog uključivanja u sastav Beograda (1934), Zemun bio teritorijalno nadležan za deo prostora na levoj obali Save, lokalna uprava je pretendovala da i sama, shodno sopstvenim interesima, učestvuje $u$ procesu njegove urbane izgradnje. U skladu s činjenicom da saznanja o toj temi postoje samo u elementarnom vidu, ovaj rad predstavlja pokušaj da se ona prošire i sistematizuju. U njemu će biti rekonstruisan nastanak i razvoj planova za širenje Zemuna na prostor leve obale Save u periodu 1918-1934, to jest u vreme kada je Zemun imao status samostalne gradske opštine. Kao izvorna osnova za tu rekonstrukciju prvenstveno je poslužila dokumentarna građa iz Istorijskog arhiva Beograda, koja prethodno nije korišćena u literaturi.

Ideja o širenju na tlo potonjeg Novog Beograda nastala je kod zemunskih vlasti još u vreme kad se Zemun nalazio pod austrougarskom vlašću. U to doba ovaj teren je bio neizgrađen i mahom vodoplavan prostor koji je grad razdvajao od Save, duž koje se prostirala tadašnja državna granica. U administrativnom pogledu, on je bio podeljen između Zemuna i bežanijske seoske opština i ovu podelu je kasnije nasledila novoformirana Kraljevina SHS. Teritoriji grada pripadao je manji, severni deo koji je prema Građevnom statutu Zemuna iz 1907. ${ }^{3}$ obuhvatao drugu zonu IV i ceo V gradski kotar. To zemljište, smešteno u produžetku jugoistočnog dela grada, bilo je omeđeno ulicom Tošin bunar na zapadu, nekadašnjom železničkom prugom ${ }^{4}$ i Dunavom na severu, Savom na istoku i administrativnom granicom sa Bežanijom na jugu. Ceo kompleks bio je podeljen železničkim nasipom pruge Beograd-Zemun, kao svojevrsnim hidrotehničkim bedemom, na dva segmenta: 1) nezaštićeni spoljašnji vodoplavni teren (između nasipa i Save), direktno izložen plavljenju reka; 2) zaštićeni unutrašnji

${ }^{1}$ Više o prostoru leve obale Save u međuratnom periodu videti: Ljiljana Blagojević, Novi Beograd: osporeni modernizam, Beograd 2007; Jovan Marković, Novi Beograd 19481968, Novi Beograd 1968; Milorad Čukić, Slobodan Kokotović, Novi Beograd: Prva naseljaSavremeni grad, Beograd 1981; Zoran Nikolić, Mirko Radonjić, Tajna Novog Beograda, Beograd 2010; Ranka Gašić, Planovi za izgradnju Beograda na levoj obali Save u međuratnom periodu, naučni skup Prostorno planiranje u jugoistočnoj Evropi (do Drugog svetskog rata), 2728. novembar 2009, Beograd.

${ }^{2}$ Goran Antonić, Regulacioni plan Zemuna za područje leve obale Save iz 1932, Istorija 20. veka, br. 1, Beograd 2012, 217-227.

${ }^{3}$ Nikola Pavlović, Zbirka statuta, propisnika, naredaba i ugovora u političko-administrativnoj upravi grada Zemuna, I, Zemun 1907, 87-108.

${ }^{4}$ Nekadašnja železnička pruga na jugoistočnom obodu Zemuna. Njena trasa je išla duž današnjih ulica Jerneja Kopitara i Prve pruge. 
vodoplavni teren (između nasipa i ulice Tošin bunar), Bare, ${ }^{5}$ podložan uticaju podzemnih i atmosferskih voda. ${ }^{6}$

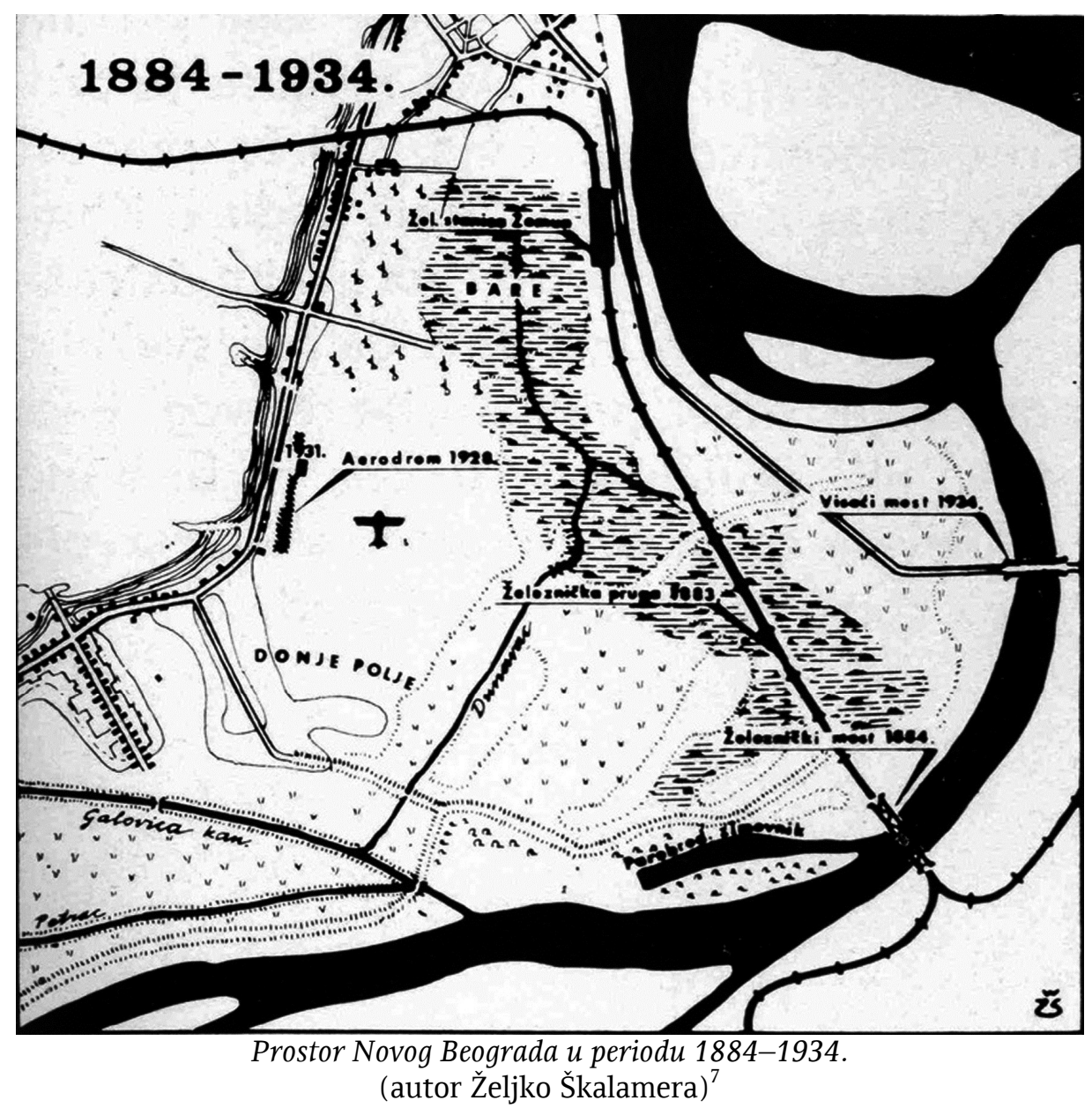

Zemun je počeo da se širi prema ovim prostorima tek posle 1876 , kada je doneta odluka o rušenju fortifikacionog zida na „beogradskoj“ stra-

${ }^{5}$ Danas bi to bilo zemljište „između ulica Tošin bunar, Jerneja Kopitara, Prve pruge, Džona Kenedija, Bulevara Nikole Tesle, Bulevara umetnosti i ulice Pariske komune"; citirano prema: Milan Leko, Beogradske ulice i trgovi 1872-2003, Beograd 2003, 26.

${ }^{6}$ Osim železničkim nasipom, to područje bilo je zaštićeno i tzv. Bežanijskim nasipom. Ovaj hidrotehnički objekat, namenjen zaštiti od Save, napravili su Austrijanci krajem XVIII veka; videti: Željko Škalamera, Područje Novog Beograda na istorijskim planovima, Urbanizam Beograda, br. 25, Beograd 1973, 38.

7 Željko Škalamera, Područje Novog Beograda na istorijskim planovima, Urbanizam Beograda, br. 25, Beograd 1973, 39. 
ni naselja. ${ }^{8}$ Tada započeto širenje bilo je usmereno na površine locirane pretežno uz obalu Dunava, gde se u narednim decenijama postepeno stvarala nova privredno-industrijska zona grada. Početkom XX veka, ova zona, koja je u znatnoj meri obeležila početak procesa industrijalizacije i modernizacije Zemuna, dosegla je do teritorije Bara i spoljašnjeg inundacionog terena.

Budući da su postojale namere da se ona i dalje izgrađuje, zemunske vlasti su drugu zonu IV-og i V kotar načelno odredile za podizanje industrije, što je definisano i odredbama zemunskog Građevnog statuta. Ovakvoj strategiji razvoja odgovaralo je i prisustvo nekadašnje železničke stanice Zemun $^{9}$ na granici s pomenutim kotarima. Uz vodotok Dunava, ona je pružala mogućnosti za ekonomičan i lak transport neophodnih sirovina i proizvedene robe, što je bio bitan podsticaj daljoj izgradnji privrednih objekata. Zbog bezbednosti od rečnih poplava, teren Bara je naročito bio podesan za gradnju, pa su pred Prvi svetski rat započete čak i pripreme za njegovo korišćenje. Preduzimajući šire mere na zaštiti jugoistočnog dela grada od visokih vodostaja Dunava, zemunska uprava je na tom području prokopala tokom 1909. i 1910. dva odvodna kanala, ${ }^{10}$ koja su priključena na novoizgrađeni melioracioni sistem Zadruge za isušivanje jugoistočnog Srema. ${ }^{11}$ Mada se samo kanalima nije mogao rešiti problem potpunog i trajnog isušivanja tla u Barama, gradske vlasti su po okončanju radova sprovele parcelizaciju dela tog terena, radi njegovog davanja u zakup. ${ }^{12}$ Reč je bila o prostoru Gradske šume, ${ }^{13}$ smeštenom u zaleđu železničke stanice i nasipa. To zem-

${ }^{8}$ Željko Škalamera, Staro jezgro Zemuna I, Beograd 1966, 22-23.

${ }^{9}$ Nekadašnja železnička stanica Zemun koja se nalazila kod današnjeg hotela Jugoslavija. Izgradili su je Austrougari 80-ih godina XIX veka, a srušena je krajem 60-ih godina XX veka, kao smetnja daljoj izgradnji Novog Beograda.

${ }^{10}$ Istorijski arhiv Beograda (dalje IAB), fond Skupština opština Zemun (dalje SO Zemun) - nesređeni fond, inventarni broj (dalje inv. br.) 240, fascikla (dalje fasc.) 556, Izveštaj, (autor) Hinko Celer, 13. septembar 1927. Glavni kanal bio je produženje nekadašnje rečice Dunavac prema Zemunu i proticao je sredinom Bara. Na njega su bili priključeni gradski kanali, kojima je odvođen višak vode sa ugroženih područja na jugoistoku grada. Drugi kanal je počinjao kod nekadašnje železničke stanice i protezao se uz železnički nasip do područja bežanijske opštine, odakle se nastavljao duž opštinske granice do kanala Dunavac. Imao je funkciju da u vreme visokog vodostaja Dunava sakuplja i odvodi vodu koja je prolazila ispod železničkog nasipa.

${ }^{11}$ O Zadruzi videti: Miladin Vujović, Zdeslav Raštegorac, Zadruga za isušenje jugoistočnog Srema - 1902. godina. Vodoprivredno preduzeće "Galovica“ d. p. - 2002. Monografija, Zemun 2002.

${ }^{12}$ IAB, SO Zemun, inv. br. 240, fasc. 556, Zapisnik VI redovne skupštine gradskog zastupstva, 18. jun 1909.

${ }^{13}$ Gradska šuma (druga zona V kotara) nalazila se između nekadašnje železničke stanice i puta koji je u međuratnom periodu bio produžetak Tvorničke ulice na tlu budućeg Novog Beograda. Sam naziv „Gradska šuma“ bio je u upotrebi do sredine dvadesetih godina 
ljište se nalazilo u posedu opštine zbog čega nisu postojale smetnje za njegovo davanje u zakup. Započete aktivnosti, međutim, sprečio je početak Prvog svetskog rata, pa su one nastavljene po njegovom završetku, u okviru nove jugoslovenske države.

Nastankom Kraljevine SHS (1918) uslovi za razvoj područja budućeg Novog Beograda nisu više ostali isti, pa je ovo uticalo i na ideje o širenju Zemuna na taj teren. Najznačajnija promena bila je ukidanje nekadašnje granice na Savi, čime su stvorene mogućnosti za izgradnju Beograda na teritoriji leve obale reke. Taj pravac širenja bio je prirodan za Beograd, a u postojećim okolnostima odgovarao je i njegovim razvojnim potrebama kao sedišta nove, teritorijalno uvećane države. Iz perspektive prostornog rasta glavnog grada, prednosti ekspanzije preko Save bile su dvojake - izgradnja na relativno maloj udaljenosti od užeg gradskog jezgra i integracija manjeg, susednog Zemuna. Ideja o proširenju prestonice na ovo područje pojavila se ubrzo po formiranju države, ${ }^{14}$ a nedugo potom ona biva uobličena i kroz pojedine urbanističke projekte, koji su pratili izradu Generalnog urbanističkog plana Beograda iz 1923. ${ }^{15}$ Tih godina, čak, državne vlasti sprovode i pripreme oko izgradnje (prvog) beogradskog aerodroma, na bežanijskom delu područja kasnijeg Novog Beograda (završen 1927). ${ }^{16}$ U tadašnjoj situaciji, kada granice administrativne nadležnosti Beograda još nisu prelazile Savu, to je bio prvi konkretan nagoveštaj potencijalnog pravca njegovog budućeg širenja. Pa ipak, plansko podizanje novog dela grada na suprotnoj obali reke predstavljalo je u aktuelnom trenutku samo viziju, posebno stoga što je ovaj poduhvat zahtevao izuzetno velika finansijska sredstva. U tom pogledu, veliku prepreku činilo je to što je prestonica bila nepovezana saobraćajnom infrastrukturom sa ovim terenom, kao i činjenica da ovaj teren, zbog vodoplavnosti, zahtevao sistematsko nasipanje, pre bilo koje druge vrste građevinskih radova.

Kad je reč o Zemunu, njegov odranije prisutan interes za područje potonjeg Novog Beograda postao je u novim prilikama još intenzivniji. Na to su uticala dva faktora. Prvi se odnosio na nove uslove razvoja tog zemljišta, koje je zbog položaja Beograda i Zemuna, kao i ideje o njihovom povezivanju, sada postalo mnogo perspektivniji građevinski prostor. U tim okolnostima, pitanje izgradnje terena na levoj obali Save prirodno je privlačilo pažnju i zemunskih vlasti, posebno zato što su one bile nadležne za jedan njegov deo. Rezultat toga bile su nove pretenzije koje su se po tom pitanju

XX veka, kada biva zamenjen nazivom „Bare“. Danas, teritoriju nekadašnje Gradske šume dele opštine Novi Beograd i Zemun (oko hotela Jugoslavija).

${ }^{14}$ Za uređenje Beograda, Politika, 24. jul 1920.

${ }^{15} \mathrm{Lj}$. Blagojević, n. d., 21-24.

${ }^{16}$ O izgradnji beogradskog aerodroma videti: Čedomir Janić, Jovo Simišić, Više od letenja: Osam decenija Aeroputa i JAT-a, Beograd 2007, 16-17. 
pojavile u lokalnoj upravi, pre ukidanja njene samostalnosti 1934. godine. Drugi, pak, faktor bio je u vezi sa potrebama industrijskog razvoja Zemuna. Naime, po njegovom ulasku u sastav nove države naglo je stvorena potreba za promenama u strukturi gradske privrede koja, zbog konkurencije Beograda, više nije mogla da prihoduje od trgovine kao u vreme austrougarske vladavine. Budući privredni napredak, od čega je zavisio i opštinski budžet, sada je, prema mišljenju zemunskih vlasti, trebalo da počiva na masovnoj gradnji industrije. ${ }^{17} \mathrm{Na}$ taj način, pusti tereni IV i V kotara, već određeni Građevnim statutom za industrijske potrebe, postali su potencijalno značajniji za razvoj grada. To se prevashodno odnosilo na područje Gradske šume $\mathrm{u}$ Barama ${ }^{18}$ zbog njegovog povoljnog položaja i priprema učinjenih pre Prvog svetskog rata. Veliki podsticaj za gradnju na ovom terenu davali su i sami preduzetnici, koji su već od prvih godina postojanja nove države pokazivali znatan interes za njega. Tako je, prema jednom spisku iz marta 1923, postojalo 13 lica i preduzeća koji su u tom trenutku tražili od vlasti Zemuna da im se dodele parcele u Gradskoj šumi radi podizanja fabričkih postrojenja i stovarišta. ${ }^{19}$

U stručnoj literaturi ostalo je dosad nepoznato da je verovatno najstariji plan za uređenje područja kasnijeg Novog Beograda izrađen u zemunskoj upravi. Na to ukazuje činjenica da je još početkom aprila 1920. gradski građevinski odsek napravio nacrt kojim je regulisan celokupan prostor na levoj obali Save pod nadležnošću Zemuna, zajedno sa delom teritorije bežanijske opštine. Sam nacrt nije sačuvan, ali jeste njegovo idejno obrazloženje, pod nazivom „Tehnički opis generalne regulatorne osnove IV i V kotara grada Zemuna". ${ }^{20}$

Neposredan povod za izradu nacrta bila je molba kompanije Eternit za podizanje fabrike škriljaca na tlu Gradske šume. ${ }^{21}$ Budući da su lokalnim vlastima već upućivane slične molbe, kao i da traženo zemljište nije ranije bilo predmet regulacije, građevinski odsek je, na sopstvenu inicijativu, napravio inicijalni plan uređenja teritorija IV i V kotara, kako bi se stekla osnova za njihovu potencijalnu izgradnju. ${ }^{22}$ Istovremeno, ispunjenje ovog zahteva bilo je usklađeno s rešavanjem pitanja integracije Zemuna i Beo-

${ }^{17}$ IAB, SO Zemun, inv. br. 268, fasc. 611, br. 3629/1923, 13. april 1923.

${ }^{18}$ Isto.

${ }^{19}$ IAB, SO Zemun, inv. br. 251, fasc. 567, Izvadak iz zapisnika tehničko-regulatornog pododbora, br. 2352, 3. mart 1923.

${ }^{20}$ IAB, SO Zemun, inv. br. 251, fasc. 567, Tehnički opis generalne regulatorne osnove IV i V kotara grada Zemuna, 9. april 1920.

${ }^{21}$ IAB, SO Zemun, inv. br. 251, fasc. 567, Molba kompanije Eternit za izgradnju fabrike škriljaca, 5. mart 1920.

${ }^{22}$ IAB, SO Zemun, inv. br. 251, fasc. 567, Dopis građevinskog odseka Gradskom poglavarstvu u Zemunu, br. 348/gr. ur.(1920), 17. maj 1920. 
grada, zbog čega je planom bio obuhvaćen i „veliki kompleks“ zemljišta, koje je trebalo da se izdvoji iz sastava bežanijske opštine. Budući da je povezivanje dvaju susednih gradova trebalo sprovesti „razvitkom Zemuna“, možemo pretpostaviti da bi ovo zemljište kasnije pripalo zemunskoj opštini, ali to nije moguće tvrditi sa sigurnošću zbog nepreciznosti teksta regulatornih osnova. ${ }^{23}$

S tehničke strane, nacrt se zasnivao na „pretpostavci“ o izradi dve glavne saobraćajne arterije na prostoru leve obale Save, koje bi, uz dva nova mosta, omogućile spajanje Zemuna i Beograda. Jednom komunikacijom ${ }^{24}$ grad bi se direktno povezao s centrom prestonice i njom bi se obavljao lokalni kolski i tramvajski saobraćaj. Drugom komunikacijom ${ }^{25}$ trebalo je regionalni saobraćaj, koji je iz šireg zaleđa Zemuna išao ka Beogradu, usmeriti na zaobilaznu trasu preko Ade Ciganlije, Čukarice i Topčiderskog druma. $\mathrm{Na}$ taj način bi se rasteretila jezgra oba grada. Kao preduslov izgradnje na spoljašnjem inundacionom terenu bilo je predviđeno podizanje odbrambenog nasipa duž obala Save i Dunava, na potezu Zemun - železnički most na Savi. To zemljište bi se potom nasulo, za šta bi se eventualno iskoristio pesak sa Malog ratnog ostrva. U skladu sa Građevnim statutom, za potencijalne korisnike ovog područja predviđena su industrijska i trgovačka preduzeća, pa je raspored ulica napravljen tako da su ostavljeni veći blokovski kompleksi. Saglasno pomenutom statutu, industriju je trebalo smestiti i na prostoru Bara, čemu je koncept regulacije takođe bio prilagođen. I deo tog terena trebalo je najpre nasuti (Gradsku šumu), a u tu svrhu bi se napravila uskotračna pruga, kojom bi se dovlačila zemlja iz okoline grada. Zbog „niskog terena" na levoj obali Save bilo je neophodno napraviti i adekvatan sistem kanalizacije, ali je u regulaciji to pitanje rešeno samo u osnovnim crtama. Predviđeno je pravljenje vodocrpne stanice kod ušća nekadašnjeg kanala Dunavac (nasuprot Malog ratnog ostrva), jer se to zemljište nalazilo na nešto nižoj nadmorskoj visini. ${ }^{26}$

$\mathrm{Na}$ osnovu sačuvanih izvora nije moguće utvrditi zbog čega zemunske vlasti nisu kasnije usvojile ovaj nacrt. Poznato je da je on trebalo da bude upućen nadležnim opštinskim organima na dalju verifikaciju, ali ne i šta se s njim potom desilo. ${ }^{27}$ Ujedno, to je i poslednja vrsta saznanja koja se

${ }^{23}$ IAB, SO Zemun, inv. br. 251, fasc. 567, Tehnički opis generalne regulatorne osnove IV i V kotara grada Zemuna, 9. april 1920.

${ }^{24}$ Ta saobraćajnica bi se vezivala za nekadašnju ulicu Kralja Petra (danas Glavna) i išla bi do nekadašnje železničke stanice, odakle bi se nastavljala dunavskom obalom do Malog ratnog ostrva, gde bi zatim skretala u pravcu mosta na Savi.

${ }^{25}$ Ta saobraćajnica bi se vezivala za nekadašnju Vrtljarsku ulicu i prolazila bi kroz Gradsku šumu, odakle bi išla do zimovnika na Savi i mosta preko Ade Ciganlije.

${ }^{26}$ IAB, SO Zemun, inv. br. 251, fasc. 567, Tehnički opis generalne regulatorne osnove IV i V kotara grada Zemuna, 9. april 1920.

${ }^{27}$ IAB, SO Zemun, inv. br. 251, fasc. 567, br. 4694/20, 26. jun 1920. 
generalno o njemu može naći u dokumentima. S obzirom na to, možemo samo da pretpostavimo da su razlozi neusvajanja nacrta bili njegova neusklađenost sa aktuelnim mogućnostima i potrebama Zemuna, kao i njegova provizornost $u$ pojedinim značajnim tehničkim elementima. Tako, na primer, položaj mosta na Savi (budući most kralja Aleksandra I), kao i trasa puta Beograd-Zemun tada još nisu bili određeni, a predstavljali su važan činilac u definisanju rasporeda saobraćajnih komunikacija. Mogli bi, stoga, da zaključimo da je nacrt više predstavljao poželjnu projekciju širenja Zemuna na tlo leve obale Save nego realan program razvoja grada. Pa ipak, njegova pojava bila je pokazatelj da se u zemunskoj upravi vrlo rano razmišljalo o široj izgradnji na prostoru potonjeg Novog Beograda. U tom smislu, on je predstavljao ne samo nagoveštaj kasnijih pretenzija lokalne uprave već je, po svemu sudeći, i uticao na njih u pojedinim idejnim segmentima. ${ }^{28}$

U prvim godinama postojanja Kraljevine SHS, vlasti Zemuna bile su daleko zainteresovanije za izgradnju na znatno užem području budućeg Novog Beograda. U pitanju je bila teritorija Gradske šume, na kojoj je, zbog već pomenutih potreba industrijskog razvoja, trebalo što hitnije krenuti s podizanjem fabričkih objekata. Kako se sa gradnjom nije moglo početi bez plana regulacije, gradska skupština je donela odluku o njegovoj izradi septembra 1922. Tokom narednih meseci građevinski odsek je napravio nacrt „regulacionih osnova" ovog područja, koji je usvojen u gradskoj skupštini marta 1923. Međutim, zbog primedbi nadležne Građevinske direkcije iz Novog Sada, on je morao biti prepravljen u pojedinim delovima. U saradnji sa novosadskom Direkcijom napravljen je nov nacrt, koji je gradska skupština usvojila u martu 1924, kao definitivan plan regulacije Gradske šume. ${ }^{29}$ U njemu su definisane najniže visinske kote za nasipanje terena i nivelete ulica, raspored ulica i blokovskih parcela, uređenje kanalizacione mreže i dr. Budući da je ovo područje bilo određeno za industrijsku zonu, projektovane su, pored manjih, i veće blokovske parcele, više prilagođene gradnji privredne infrastrukture. ${ }^{30}$

Već naredne godine (1925) sagrađen je prvi industrijski objekat na tlu Gradske šume. To je bila fabrika za preradu kostiju i životinjskih otpadaka - Munk, podignuta u Tvorničkoj ulici, nedaleko od nekadašnje železničke pruge. Fabrički kompleks, koji je u svom sastavu imao više objekata, bio je smešten na placu površine oko 20.000 kvadratnih metara. U njemu je

${ }^{28} \mathrm{Na}$ primer, ideja o mostu preko Ade Međice i obilaznoj saobraćajnoj vezi s Beogradom ponovo se pojavljuje u jednom docnijem planu Zemuna za regulaciju prostora leve obale Save, o kom će više biti reči kasnije u tekstu.

${ }^{29}$ IAB SO Zemun, inv. br. 251, fasc. 567, Predmet: Regulacija Bara, br. 6324-1926, 6. maj 1926.

${ }^{30}$ IAB, SO Zemun, inv. br. 251, fasc. 567, Zapisnik sa II redovne skupštine zastupstva grada Zemuna, 25. mart 1924. 
bilo zaposleno prosečno 75 radnika, a njegova ukupna vrednost iznosila je oko 6 miliona dinara. ${ }^{31} \mathrm{U}$ blizini nekadašnje železničke stanice sagrađena je dve godine kasnije i fabrika za izradu aviona - Ikarus. U tom fabričkom pogonu proizvodile su se letelice namenjene jugoslovenskoj vojsci. Ugovor o proizvodnji, preduzeće je sklopilo sa državom 1927, s rokom od pet godina. Krajem treće decenije prošlog veka u fabrici, koja je tada zapošljavala oko 250 radnika, godišnje je pravljeno oko 150 aviona. $^{32}$

Sredinom dvadesetih godina zemunske vlasti su, takođe, pokušale da zonu industrije prošire i na spoljašnji vodoplavni teren. O tome svedoči ugovor sa američkim preduzećem Standard oil (Standard oil Co. of Yugoslavia) kojim je bila predviđena gradnja postrojenja za naftne proizvode. Taj kompleks je trebalo da bude smešten na dunavskoj obali, nasuprot (zapadnog kraja) Malog ratnog ostrva, radi čega je gradska uprava ustupila preko 27 jutara opštinske zemlje. ${ }^{33} \mathrm{U}$ januaru 1926. napravljen je i projekat kompleksa, čije je autor bio inženjer Miladin Pećinar, ${ }^{34}$ ali je Standard oil kasnije odustao od gradnje, pa do realizacije ove ideje nikad nije došlo.

Aspiracije zemunskih vlasti ka razvoju industrije na opštinskom području kasnijeg Novog Beograda našle su svoju potvrdu i tokom izrade Generalnog regulacionog plana Zemuna iz 1930. godine. Iako samim planom pitanje uređenja spoljašnjeg vodoplavnog terena nije bilo rešeno, u programu konkursa za njegovu izradu navedeno je da se „za industriju predviđa ceo prostor, koji se proteže od pravca željezničke pruge do skretanja prema jugu, Tvorničke ulice i Dunava i Save“. Pomenuta je i mogućnost formiranja radničkih četvrti na tom terenu, ali samo unutar fabričkih poseda i za potrebe dotičnih fabrika. U programu je dotaknuto i pitanje integracije Beograda i Zemuna, u vezi s čim je konstatovano da „svi su izgledi, da će se i budući veliki Beograd morati razvijati na istom platou, kao i Zemun, a to je od Bežanijske kose prema Dunavu“. ${ }^{35}$ Inače, procena je bila da će do spajanja susednih gradova doći za nekoliko decenija, a dotad, Zemun je trebalo da se razvija

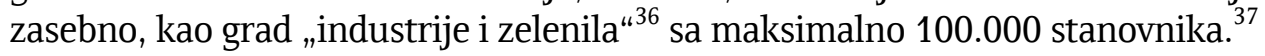

${ }^{31}$ Dragan Petrović, Istorija industrije Beograda, I, Beograd 2006, 144.

32 Joso Lakatoš, Privredni almanah jugoslovenskog Lloyda, Zagreb 1929, 73; Nikola Žutić, Ikarus-Ikarbus 1923-1998, Beograd 1998, 18; Petnaestogodišnjica fabrike aeroplana i hidroplana Ikarus S. A, Godišnjak jugoslovenskog vazduhoplovstva, 1938.

${ }^{33}$ IAB, SO Zemun, inv. br. 239, fasc. 554/II, Zapisnik IV redovne skupštine zastupstva grada Zemuna, 15. april 1931.

${ }^{34}$ IAB, SO Zemun, inv. br. 256, fasc. 574, Mapa Generalnog plana instalacija naftnih proizvoda u Zemunu, (autor) Miladin Pećinar, 26. januar 1926.

${ }^{35}$ IAB, SO Zemun, inv. br. 275, fasc. 619, Program natečaja za izradu generalnog plana o uređenju i proširenju Zemuna, 16. januar 1929.

${ }^{36}$ IAB, SO Zemun, inv. br. 275, fasc. 620, Ekspoze gradskog inženjera Đorđa Šuice, 18. april 1928.

${ }^{37}$ Prema nekim procenama Zemun je u tom trenutku imao 25.000 stanovnika. 
Do radikalne promene planova, kao i do intenzivnog povećanja interesovanja zemunske uprave za izgradnju na području potonjeg Novog Beograda došlo je naglo, početkom tridesetih godina. Uzrok tome bila je paralelna gradnja budućeg mosta kralja Aleksandra i puta Beograd-Zemun, koju je, kao veliki i skup građevinski poduhvat, sprovodila država. Ideja o pravljenju ovih saobraćajnih objekata postojala je od samog osnivanja Kraljevine SHS, ali je zbog nedostatka finansijskih sredstava njena realizacija prolongirana sve do 1930, kada su obavljeni prvi radovi. Značaj novog mosta i puta bio je veliki, jer je njima prvi put trebalo direktno povezati prestonicu ne samo sa susednim Zemunom već i sa sremskim zaleđem i daljim krajevima na severu i zapadu zemlje. ${ }^{38}$ Takođe, njihova izrada trebalo je da bude i glavni preduslov za širenje Beograda na prostor leve obale Save i integraciju Zemuna, ${ }^{39}$ kao prvom koraku u formiranju tzv. Velikog Beograda. ${ }^{40}$ Zakonska podloga za to stvorena je još 1929. kada je Zemun potpao pod nadležnost Uprave grada Beograda, ${ }^{41}$ a uz novu saobraćajnu infrastrukturu očekivao se i vrlo skori početak tog procesa. U tim okolnostima, prostor leve obale Save je još tokom radova na novom mostu i putu postao atraktivan građevinski prostor, za koji su se interesovali „domaći i strani kapitali i tehnički krugovi“. ${ }^{42}$

Izrada novih saobraćajnih objekata predstavljala je za zemunske vlasti ključan podsticaj za preduzimanje opsežnih priprema u cilju izgradnje na spoljašnjem vodoplavnom terenu. U odnosu na pređašnje, glavni razlog za to sada je bila potencijalna finansijska dobit koju je grad mogao da ostvari od prodaje građevinskih placeva na tom području. Po završetku novog mosta i puta očekivalo se da će ovo, dotad gotovo bezvredno zemljište imati ogromnu vrednost zbog svoje male udaljenosti od najužeg centra prestonice - oko kilometar od Terazija. Takođe, preko njega je išla trasa novog puta, pa je ono bilo i najpogodnije za buduće spajanje Beograda i Zemuna. Na njegovu potencijalnu vrednost ukazivala je, između ostalog, i ponuda jedne američke firme (1929), koja

${ }^{38}$ Za deset dana biće završeni i poslednji radovi na Zemunskom mostu, Pravda, 11. novembar 1934.

${ }^{39}$ Radovi na Zemunskom mostu Kralja Aleksandra I, Politika, 24. jul 1931.

${ }^{40}$ Međuratna ideja o „Velikom Beogradu“ bila je projekcija dugoročnog razvoja prestonice, prema kojoj je Beograd trebalo da obuhvati Zemun i Pančevo, kao delove jedinstvene urbane celine.

${ }^{41}$ Zakonom o novoj upravnoj podeli zemlje iz oktobra 1929, formirano je zasebno administrativno područje za prestonicu (van novouspostavljenih banovina) - Uprava grada Beograda, koje je obuhvatalo gradove Beograd, Zemun i Pančevo. Iako formalno podređeni Upravi, Zemun i Pančevo su i dalje funkcionisali kao samostalne gradske opštine. Videti: Kraljevina Jugoslavija, Politika, 4. oktobar 1929.

${ }^{42}$ Savska plaža, od železničkog mosta do ušća Save u Dunav pretvoriće se u novo predgrađe Prestonice, Vreme, 12. oktobar 1931. 
je htela da ga otkupi u celini. ${ }^{43}$ Iz tih razloga zemunska uprava je odlučila da ovo zemljište prvo pripremi za gradnju, kako bi ga kasnije postepeno prodavala i tako obezbedila investicije za druge značajne gradske potrebe. U skladu s tom zamisli, određeno je da se najpre napravi regulacioni plan za to područje, a potom da se ono zaštiti obaloutvrdama duž obe reke i naspe do odgovarajuće visinske kote. Predviđen rok završetka svih poslova bio je tri godine. ${ }^{44}$

Za izradu preliminarnog koncepta regulacije zemunske vlasti su angažovale uglednog stručnjaka Đorđa Kovaljevskog, ${ }^{45}$ verovatno početkom 1931. godine. Moguće je da su razlozi takvog izbora bili dvojaki. Prvo, Kovaljevski je već bio upoznat sa problemima uređenja prostora leve obale Save, jer je još tokom učešća u izradi Generalnog urbanističkog plana Beograda iz 1923, samoinicijativno napravio jedan projekat za proširenje prestonice na to područje. ${ }^{46}$ Drugo, on je, kao dugogodišnji rukovodilac odseka za urbanistička pitanja u beogradskoj opštini, mogao da usaglasi zemunski koncept regulacije s potrebama razvoja Beograda, što je inače bio jedan od zahteva lokalnih vlasti. ${ }^{47}$ To je, pak, bilo značajno zbog kasnijeg odobrenja plana od strane nadležnih državnih organa.

Sem Kovaljevskog, za pojedine segmente uređenja spoljašnjeg vodoplavnog terena zemunske vlasti su istovremeno angažovale i inženjera Vladimira Mitrovića, tadašnjeg rektora Beogradskog univerziteta. Mitrovićev zadatak bio je da napravi inicijalni predlog izgradnje gradskog vodovoda i kanalizacije, koji je trebalo da obuhvati i svu opštinsku teritoriju do Save. S tim u vezi, on je trebalo da predloži tehničke mere za saniranje tog terena, kao i sistem vodosnabdevanja i kanalizacije za potrebe naselja koje bi se tu kasnije izgradilo. ${ }^{48}$

${ }^{43}$ Podvodno zemljište preko puta Savskog pristaništa pretstavljaće jedan od najuređenijih krajeva budućeg velikog Beograda, Vreme, 24. mart 1932.

${ }^{44}$ IAB, SO Zemun, inv. br. 268, fasc. 611, Zapisnik VIII redovne skupštine zastupstva grada Zemuna, 10. septembar 1931.

${ }^{45}$ Đorđe Kovaljevski je rođen 1888. u Jelisavetgradu u Rusiji (danas Kirovgrad u Ukrajini). Završio je Tehnički fakultet u Kijevu, u kojem je kasnije radio kao šef službe za regulacioni plan grada i kao profesor na Politehničkom institutu. Rusiju je napustio posle Oktobarske revolucije i u Beograd je došao 1920. Bio je zaposlen u beogradskoj opštinskoj upravi do 1944, gde je rukovodio sektorom za urbanističko planiranje. Poznat je po učešću u izradi Generalnog urbanističkog plana Beograda iz 1923, uz koji je napravio jedan od prvih planova za širenje Beograda na levu obalu Save. Kao arhitekta projektovao je više značajnih objekata, a među najpoznatijima je zgrada studentskog doma „Kralj Aleksandar I“ u Beogradu; videti: Marina Đurđević, Urbanističko-arhitektonska delatnost Đorđa Pavloviča Kovaljevskog u Srbiji, Godišnjak grada Beograda, br. XLIX - L, 2002-2003, str. 169-181.

${ }^{46}$ Lj. Blagojević, $n$. d., 24.

${ }^{47}$ IAB, SO Zemun, inv. br. 239, fasc. 554/II, Zapisnik nastavljene II redovne skupštine zastupstva grada Zemuna, 20. februar 1931.

${ }^{48}$ IAB, SO Zemun, inv. br. 268, fasc. 611, Izveštaj inženjera Vladimira Mitrović o vodovodu i kanalizaciji grada Zemuna, 15. februar 1931. 
U februaru 1931. predlozi dvojice stručnjaka ${ }^{49}$ bili su završeni i dostavljeni zemunskoj upravi. Na osnovu njih sastavljene su smernice za izradu regulacionog plana koje je gradska skupština usvojila $u$ toku istog meseca ${ }^{50}$ Polazna postavka smernica bila je da se projekat regulacije napravi ne samo za spoljašnji vodoplavni teren, ${ }^{51}$ kako je prvobitno zamišljeno, već za celokupan prostor, gotovo do Bežanije. ${ }^{52}$ Njima je, takođe, bila predviđena i asanacija zemunskog i bežanijskog vodoplavnog terena koji nije bio zaštićen nasipima - trougao između Save, Dunava i železničkog nasipa. Način asanacije, međutim, nije bio definitivno utvrđen, pa su smernicama bile obuhvaćene dve mogućnosti: 1) pravljenje odbrambenih nasipa i nasipanje zemljišta do kote 73.0 metara (iznad nivoa podzemnih voda) - jeftinija varijanta 2) nasipanje do kote 75.5 metara (iznad najviših vodostaja reka). Na asaniranom području trebalo je izgraditi središte novog dela grada, u vidu zone tzv. "gustog naselja sa pristaništem i industrijskim kolosecima". Za samo naselje bilo je predviđeno $65 \%$ prostora, dok bi ostalo zauzeli kejovi, ulice i dr. Pristanište bi bilo izgrađeno na Dunavu, s tim što je njegova lokacija, takođe, bila određena u dve varijante: 1) između Ade Vrbak $^{53}$ i kopna; 2) između Malog ratnog ostrva i kopna (s tim da se rukavac kod Ade Vrbak prethodno zatrpa). Postojeća železnička stanica Zemun bi se zadržala na svom mestu, uz eventualno proširenje prema Bežaniji, radi potreba budućeg stanovništva. Naposletku, naselje je trebalo da se snabdeva vodom iz bunara koji bi se izgradili na savskoj obali (preko puta Makiša), dok bi njegov sistem kanalizacije bio "opšteg" tipa, sa glavnim izlivnim kanalom (za ceo grad) kod ušća Save u Dunav. ${ }^{54}$

Usvajanje smernica nije samo po sebi bilo i uslov koji su zemunske vlasti smatrale dovoljnim za početak izrade regulacionog plana. Za takav projekat bilo je važno dobiti i načelnu saglasnost nadležnih državnih organa, budući da je on prevazilazio lokalni značaj zbog planova o formiranju „Velikog Beograda“. Po rečima gradskog načelnika, ta „principijelna odo-

${ }^{49}$ Uz idejni predlog regulacije, Kovaljevski je izradio i skicu regulacionog plana; za skicu videti: IAB, SO Zemun, inv. br. 256, fasc. 567, Nacrt regulacije inundacionog terena 1 : 15.000, (autor) Đorđe Kovaljevski, 7. februar 1931.

${ }^{50}$ IAB, SO Zemun, inv. br. 239, fasc. 554/II, Zapisnik nastavljene II redovne skupštine zastupstva grada Zemuna, 20. februar 1931.

${ }^{51}$ Na predlog Kovaljevskog; videti: IAB, SO Zemun, inv. br. 268, fasc. 611, Predlog Đorđa Kovaljevskog za regulaciju zemunskog inundacionog terena, 16. februar 1931.

${ }_{52}$ Precizno, granica regulacije trebalo je da ide duž linije koja bi se nastavila na ulicu Tošin bunar, u pravcu Ade Međice.

${ }^{53}$ Ada Vrbak (Vrbljak) se nalazila između Malog ratnog ostrva i kopna. S kopnom je spojena 1938, tokom nasipanja dela zemljišta na levoj obali Save, koje je za potrebe beogradske opštine tada vršio konzorcijum „Danska grupa“.

${ }^{54}$ IAB, SO Zemun, inv. br. 239, fasc. 554/II, Zapisnik nastavljene II redovne skupštine zastupstva grada Zemuna, 20. februar 1931. 
brenja (bila - prim. A. G.) su potrebna iz razloga, da ne bi naši (zemunski prim. A. G.) elaborati, ${ }^{55}$ nakon što budu izrađeni sa velikim trudom i troškom, naišli posle na prigovore, te usled toga menjali, što bi povlačilo nepotrebne nove troškove i gubitak vremena" ${ }^{56}$ Iz tog razloga, zemunske vlasti su ubrzo zatražile od Ministarstva građevina formiranje mešovite komisije, koja je trebalo da ispita usvojene smernice oko regulacije prostora leve obale Save.

Po odluci ministra građevina iz marta 1931. tražena komisija je obrazovana, uz učešće predstavnika više ministarstava. ${ }^{57}$ Do sredine leta, članovi komisije su obišli prostor leve obale Save i održali nekoliko sednica, posle čega su doneli zaključke u vezi s zemunskim predlogom regulacije tog područja. Ti zaključci su, gotovo bez ikakvih izmena, potvrdili idejne postavke usvojenih smernica. Njima je, takođe, definitivno utvrđeno i da bi kota nasipanja zemunskog i bežanijskog vodoplavnog terena trebalo da bude iznad najviših vodostaja reka, kao i da bi lokacija planiranog pristaništa trebalo da bude između Ade Vrbak i kopna. ${ }^{58}$

Uz saglasnost Ministarstva građevina i Ministarstva saobraćaja na zaključke komisije, ${ }^{59}$ zemunske vlasti su konačno bile spremne da pristupe izradi regulacionog plana za prostor na levoj obali Save. S tim u vezi, lokalna uprava se ponovo obratila Kovaljevskom, s kojim je početkom oktobra 1931. postignut dogovor o pravljenju nacrta plana, za honorar u visini od 65.000 dinara. ${ }^{60}$

U martu 1932. nacrt je bio završen i, sa pratećim tehničkim objašnjenjem, ${ }^{61}$ predat zemunskoj upravi. ${ }^{62}$ Tokom aprila i maja on je izložen $u$ prostorijama zemunske uprave radi javnog uvida i kako tada nisu uložene

${ }^{55}$ Misli se na konačni regulacioni plan za uređenje prostora leve obale Save i konačnu studiju izgradnje vodovoda i kanalizacije grada Zemuna.

${ }^{56}$ IAB, SO Zemun, inv. br. 239, fasc. 554/II, Zapisnik nastavljene II redovne skupštine zastupstva grada Zemuna, 20. februar 1931.

${ }^{57}$ Komisiju su činili predstavnici Ministarstva građevina, Ministarstva saobraćaja, Ministarstva socijalne politike i narodnog zdravlja, kao i predstavnik gradske opštine Zemun.

${ }^{58}$ IAB, SO Zemun, inv. br. 275, fasc. 620, Zapisnik konferencije predstavnika Ministarstva građevina, Ministarstva saobraćaja i gradske opštine Zemun u predmetu kanalizacije, vodovoda i melioracije vodoplavnog terena u Zemunu, 26. jun 1931.

${ }^{59}$ IAB, SO Zemun, inv. br. 275, fasc. 620, Zapisnik redovne skupštine zastupstva grada Zemuna, 23. novembar 1931.

${ }^{60}$ IAB, SO Zemun. inv. br. 256, fasc. 576, Zapisnik X redovne skupštine zastupstva grada Zemuna, 2. oktobar 1931.

${ }^{61}$ IAB, SO Zemun, inv. br. 275, fasc. 620 , Tekst obrazloženja nacrta regulacionog plana Zemuna za područje leve obale Save naslovljen Gradskom načelstvu grada Zemuna, bez datuma i imena autora.

${ }^{62}$ Podvodno zemljište preko puta Savskog pristaništa pretstavljaće jedan od najuređenijih krajeva budućeg velikog Beograda, Vreme, 24. mart 1932. 
značajnije primedbe na njega, ${ }^{63}$ gradska skupština ga je usvojila početkom jula. $^{64}$

Novi plan $^{65}$ uređenja prostora leve obale Save Kovaljevski je takođe izradio u duhu Beaux Art-a kao i onaj prethodni iz 1923, ali na manje monumentalan način. Njime je bilo predviđeno da buduće gradsko naselje na tom području bude novi deo i Zemuna i Beograda, kao mesto njihovog međusobnog spajanja. Ono bi bilo podeljeno na tri zone, diferencirane po gustini naseljenosti - područje guste, srednje i retke naseljenosti. ${ }^{66}$ Kao što je prvobitno određeno, područje guste naseljenosti trebalo je da bude administrativno, poslovno i kulturno jezgro naselja. U središtu te zone bi se nalazio centralni trg, koji bi mrežom radijalno postavljenih saobraćajnica bio povezan sa ostalim delovima naselja, kao i sa Beogradom, Zemunom i Bežanijom. U centru trga bi se nalazio monumentalan spomenik, dok bi oko njega bile podignute javne građevine. Na područjima guste i srednje naseljenosti bi se izgradilo još manjih trgova i na tim mestima bi, takođe, bili podignuti spomenici i javne građevine (crkve, gimnazije, muzeji i dr.). Na prostoru čitavog naselja bi se ravnomerno rasporedila brojna dečija igrališta, a ono bi imalo i prostrane komplekse zelenih površina. Postojeći aerodrom, kao i železnička stanica Zemun bi ostali na istim lokacijama, dok bi se pristanište, kako je zaključila mešovita komisija, izgradilo između Ade Vrbak i kopna. Sama Ada Vrbak bi se spojila sa obalom na zapadnom kraju i na njoj bi se podigli magacini, koji bi železničkim kolosecima bili povezani sa železničkom stanicom. Kod pristaništa bi se nalazila glavna pijaca, oko koje bi se formirao privredni centar naselja. Takođe, uz most kralja Aleksandra bi se podigao i most na Adi Ciganliji, koji bi omogućio vezu ne samo sa Beogradom već i sa šumadijskim regionom. ${ }^{67}$

Iako je za regulacioni plan tek trebalo dobiti saglasnost nadležnih državnih organa, zemunske vlasti su odmah po njegovoj izradi nastavile s

${ }^{63}$ Direkcija državnih železnica je upozorila da će zbog predviđene regulacije biti sužen profil Save, što je u vreme visokih vodostaja moglo da ugrozi železničke objekte na desnoj obali. Komanda vazduhoplovstva je zahtevala da se u okolini aerodroma ne grade objekti u radijusu od 1000 metara.

${ }^{64}$ IAB, SO Zemun, inv. br. 283, fasc. 636, Zapisnik VIII redovne skupštine zastupstva grada Zemuna, 5. jul 1932.

${ }^{65}$ IAB, SO Zemun, inv. br. 256, fasc. 574, Regulacioni plan grada Zemuna - dela od zemunske železničke stanice do reke Save sa izmenom odobrene regulacije 1930 g., (autor) Đorđe Kovaljevski, 1932.

${ }^{66}$ 1) područje guste naseljenosti - između Save, Dunava i železničkog nasipa; 2) područje srednje naseljenosti - između industrijskog dela Zemuna (u okolini zemunske železničke stanice), železničkog nasipa, aerodroma i reke Save 3) područje retke naseljenosti ostali deo terena.

${ }^{67}$ G. Antonić, Regulacioni plan Zemuna za područje leve obale Save iz 1932, Istorija 20. veka, br. 1, Beograd 2012, 219-220. 
pripremama za izgradnju na području potonjeg Novog Beograda. Prve mere gradska uprava preduzela je već u martu, kada se obratila Ministarstvu građevina s nekoliko zahteva. Tada je zatraženo da se projekat puta BeogradZemun, kao i prilazne rampe mosta kralja Aleksandra (sa zemunske strane) koriguju prema planu Kovaljevskog. Putu, kao glavnoj saobraćajnici u pla$\mathrm{nu}$, trebalo je promeniti nagib i kotu nivelacije, kako bi on bio $\mathrm{u}$ istoj ravni sa budućim gradskim naseljem. U pogledu rampe, pak, trebalo je inicijalno planirani zemljani nasip zameniti vijaduktom, ${ }^{68}$ koji bi imao otvore za prolaz gradskih ulica. Pored ovih izmena, gradska uprava je zatražila i dozvolu za pravljenje odbrambenog nasipa između starog železničkog mosta i budućeg mosta kralja Aleksandra, ${ }^{69} \mathrm{u}$ nameri da izvrši pripreme za melioraciju dela vodoplavnog terena. ${ }^{70}$

Pregovori vođeni između predstavnika zemunske uprave i Ministarstva građevina o načinu finansiranja ovih predloga ${ }^{71}$ završeni su tokom maja. Prema tada postignutom sporazumu ${ }^{72}$ ministarstvo je prihvatilo da država snosi troškove oko korekcije puta Beograd-Zemun i izgradnje vijadukta, dok je sredstva za pravljenje odbrambenog bedema trebalo da obezbedi zemunska opština. U svrhu smanjivanja izdataka, njoj je dozvoljeno da za oblaganje te građevine prema Savi upotrebi kamen sa železničkog nasipa. Obaveza Zemuna bila je da građevinske radove završi do kraja godine. Krajem jula, ovu odluku definitivno je potvrdio i Ministarski savet. ${ }^{73}$

U skladu s preuzetom obavezom, zemunske vlasti su se već tokom leta 1932. obratile inženjeru Nikoli Cvejiću radi izrade projekta za nasip. Polazna osnova projekata bio je plan Kovaljevskog jer je, pored hidrotehničke funkcije, planirani objekat trebalo da bude i začetak jedne od ulica potonjeg naselja. Iz tog razloga on je isplaniran prema trasi buduće saobraćajnice, sa istom širinom u osnovi i odgovarajućom nivelacionom ko-

${ }^{68}$ Ta ideja je, inače, postojala i pre predloga zemunske uprave.

${ }^{69}$ AJ, fond 62, fasc. 1236, br. 21840, 2. avgust 1932; Regulisanje terena između železničkog i novog zemunskog mosta preko Save; Beogradske opštinske novine, br. 9, 1932, str. 613-614.

${ }^{70}$ Deo tih priprema bila je i studija o melioraciji terena između železničkog nasipa i nasipa pristupnog puta koju je u maju izradio inženjer Nikola Cvejić; videti: IAB, SO Zemun, inv. br. 256, fasc. 576, Studija o melioraciji terena između železničkog i drumskog nasipa Beograd-Zemun u vezi sa inundacionim terenom Bare, 23. maj 1932.

${ }^{71}$ Radi ovih pregovora zemunska opština je naručila studiju u kojoj su bili upoređeni troškovi izrade puta i prilazne rampe prema inicijalnim projektima, sa troškovima njihovih izmena, uključujući i izgradnju odbrambenog nasipa. Autori studije bili su inženjeri Vladimir Mitrović i Miladin Pećinar (kao pomoćnik); videti: IAB, SO Zemun, inv. br. 256, fasc. 575, Studija obezbeđenja od poplave terena između železničkog i drumskog nasipa Beograd-Zemun i zamena nasipa veštačkom konstrukcijom kod mosta, 27. april 1932.

${ }^{72}$ IAB, SO Zemun, inv. br. 256, fasc. 576, Zapisnik od 9. maja 1932.

${ }^{73}$ AJ, fond 62, fasc. 1236, br. 21840, 2. avgust 1932. 
tom. S kasnijom izgradnjom naselja bilo je potrebno samo proširiti vrh nasipa. ${ }^{74}$

Uprkos namerama gradske uprave da bedem što hitnije napravi, on je završen s velikim zakašnjenjem. Gotov projekat dostavljen je Ministarstvu građevina u jesen, pa je on, uz manje korekcije, odobren tek u novembru. ${ }^{75}$ Njime je utvrđeno da dužina objekta bude 1300 metara, a širina njegove krune 6 metara, s tim da se ona docnije proširi na 10 metara. ${ }^{76}$ Sledećeg meseca, firma Turner i Vagner, angažovana na gradnji nasipa, počela je pripremne radove oko raščišćavanja priobalnog terena. Odatle su ubrzo uklonjeni svi ranije nastali objekti, koje su uglavnom činila dotadašnja omiljena beogradskih kupališta - Zdravlje, Krf, Dubrovnik, Skela i dr. ${ }^{77}$ Zbog nepovoljnih klimatskih prilika, gradnja se neplanski odužila i tokom 1933, pa je, umesto tokom leta, ona definitivno okončana tek krajem novembra 1933. ${ }^{78}$ Ukupni troškovi iznosili su 1,22 miliona dinara.

Sama po sebi izgradnja novog nasipa bila je vrlo značajna za međuratni razvoj područja budućeg Novog Beograda. Osim simboličnog značaja koju je objekat imao kao prva građevina koja je nastala u skladu s nekim urbanističkim projektom, on je omogućio i pravljenje Beogradskog sajma četiri godina kasnije, čime je započeto širenje prestonice preko reke. Zahvaljujući nasipu neplanski je nastalo i prvo naselje na prostoru leve obale Save koje je nosilo ime „Novi Beograd“. Kao i Sajam, naselje je izgrađeno u neposrednom zaleđu zaštitnog bedema, između novog i starog mosta. Do početka rata 1941. ono je, prema nekim podacima, imalo više stotina kuća, kao i školu, bokserski klub, električno osvetljenje, ulice od šljake i dr. ${ }^{79}$

Pored gradnje zaštitnog bedema, aktivnosti zemunske vlasti bile su od sredine 1932. jednako usmerene i ka dobijanju saglasnosti od strane

${ }^{74}$ IAB, SO Zemun, inv. br. 256, fasc. 576, Izveštaj o parcelaciji inundacionog terenu na Bežanijskom ataru, 23. decembar 1932; IAB, SO Zemun, inv. br. 283, fasc. 636, Dopis opštinskog odeljka u Zemunu - potpredsedniku opštine grada Beograda D. Bogdanoviću, 5. maj 1934.

${ }^{75}$ IAB, SO Zemun, inv. br. 256, fasc. 576, Zapisnik XI redovne skupštine zastupstva grada Zemuna, 23. novembar 1932.

${ }^{76}$ Dva velika komunalna rada Zemunske opštine, Beogradske opštinske novine, br. 11, 1932, 754-746.

${ }^{77}$ Kao i „Hajduk Veljko“, „Ostende“, „Sloboda“, „Soko“, „Vojvoda Lune“, „Lovćen“; videti: Pred širenjem Beograda na levu obalu Save, Politika, 15. decembar 1932; Obale Dunava i Save osvojili su kupači, Politika, 16. jul 1933; prema napisu iz lista Vreme tokom leta se na „prostranu zemunsku plažu stekne desetine hiljada Beograđana“, videti: Vreme, 18. decembar 1928.

${ }^{78}$ IAB, SO Zemun, inv. br. 256, fasc. 574, Zapisnik o kolaudaciji, 3. januar 1934.

${ }^{79}$ Novi Beograd - naselje na levoj obali Save - dobio je elektriku i radio, Vreme, 31. mart 1936; R. Mandić, Divlje naselje Novi Beograd na levoj obali Save legalizovano je presudom Državnog saveta, Vreme, 9. septembar 1940; IAB, SO Zemun, inv. br. 283, fasc. 636, Dopis članova Udruženja „Novi Beograd“ - Gradskom poglavarstvu Zemun, 5. maj 1941. 
nadležnih državnih organa za usvojeni regulacioni plan Kovaljevskog. Za gradsku upravu to je bio neophodan uslov za sva dalja ulaganja oko uređivanja prostora leve obale Save, jer su u suprotnom ona mogla predstavljati samo uzaludno trošenje budžetskih sredstava.

Iako je plan poslat Ministarstvu građevina na uvid još u julu 1932, ministarstvo je tek krajem godine dostavilo svoj odgovor. Pored određenih tehničkih primedbi, odgovor je sadržao i zahtev da se u verifikaciju plana uključe svi državni organi koji su bili relevantni za pitanje regulacije prostora leve obale Save. S tim u vezi, predloženo je sazivanje zajedničke konferencije, gde bi se predstavnici tih organa okupili i izneli svoja mišljenja o planu. ${ }^{80}$ Zemunske vlasti su prihvatile ovaj predlog, pa su u skladu s njim održane dve konferencije u prvoj polovini 1933 - prva u martu, a druga u junu. ${ }^{81} \mathrm{Na}$ njima su učestvovali predstavnici Ministarstva građevina, Uprave pomorstva i rečnog saobraćaja (zbog pristaništa i keja), Direkcije državnih železnica, Komande vazduhoplovstva (zbog aerodroma), kao i beogradske, bežanijske i zemunske opštine.

Konferencije su pokazale da beogradska uprava predstavlja glavnu prepreku usvajanju regulacionog plana. Za razliku od ostalih učesnika koji su imali zamerke na pojedina tehnička rešenja, delegati beogradske opštine su plan odbacivali u potpunosti, obrazlažući to njegovom preuranjenošću. Prema njihovom uverenju pitanje prostora leve obale Save trebalo je rešiti shodno potrebama prestonice, ${ }^{82}$ a kako još nije postojala jasna ideja o tome, ceo poduhvat je trebalo odložiti za kasnije. U međuvremenu, taj prostor je, prema njihovom mišljenju, mogao da se iskoristi za formiranje zelenog pojasa. Nasuprot tome, zemunski delegati su smatrali da bi plan trebalo usvojiti što pre, argumentujući to sprečavanjem bespravne gradnje, koja je počela da se pojavljuje u zaleđu novog nasipa. Prema njihovoj proceni, veliki talas bespravne gradnje tek je trebalo očekivati po završetku mosta kralja Aleksandra, a to je u kasnijem vremenu moglo samo da naruši planski razvoj urbane strukture na tom prostoru i da dovede do mnogo većih troškova. Pored toga, zemunska strana pozivala se i na već uložen trud oko izrade projekta, zatim učešće državnih organa u njegovoj pripremi, utrošena sredstva oko podizanja zaštitnog nasipa i $\mathrm{dr}^{83}$

${ }^{80}$ IAB, SO Zemun, inv. br. 283, fasc. 636 , Regulacioni plan inundacionog terena u Zemunu. Napomene Ministarstvu građevina, br. 16913-1932, 26. januar 1933.

${ }^{81}$ Druga konferencija je organizovana jer je predstavnicima beogradske opštine trebalo više vremena da prouče regulacioni plan, dok je ostalim učesnicima omogućeno da dostave pismene primedbe na njega.

${ }^{82}$ Više o tome: Dragoslav Stojadinović, Urbanističko-tehnički problemi velikog Beograda, Beogradske opštinske novine, maj 1933, 309-313.

${ }^{83}$ IAB, SO Zemun, inv. br. 256, fasc. 574, Zapisnik konferencije u predmetu regulacije inundacionog terena Opštine zemunske i bežanijske, 20. mart 1933; IAB, SO Zemun, 
Sučeljenost Beograda i Zemuna oko izgradnje na području leve obale Save imala je i svoje ekonomske razloge. Tako su na zasedanjima Gradske skupštine beogradski odbornici iskazivali bojazan da će investicije od više desetina miliona dinara koje je grad zbog mosta kralja Aleksandra uložio u regulaciju Savske padine biti uzaludne ako se Zemunu prepusti gradnja preko Save. Odbornici su strahovali da bi to dovelo i do pada vrednosti nekretnina u Beogradu jer bi se stanovništvo masovno selilo u Zemun, gde su troškova život bili manji. ${ }^{84}$ Indikativno je da su i zemunski odbornici na svojim zasedanjima dolazili do zaključka da pitanje usvajanja regulacionog plana ne bi trebalo da zavisi od „održanja visokih cena placeva s desne obale““ ${ }^{85}$

Budući da na konferencijama nije postignuto jedinstveno stanovište oko pitanja regulacije prostora na levoj obali Save, na samom Ministarstvu građevina je ostalo da donese odluku o davanju saglasnosti za plan Kovaljevskog. ${ }^{86}$ Svoju odluku ministarstvo je donelo u julu 1933. i na osnovu nje plan je dobio potrebno odobrenje, ali sa određenim teritorijalnim ograničenjem. Naime, saglasnost se odnosila isključivo na regulaciju vodoplavnog područja između železničkog nasipa, Save i Dunava. Na taj način, preostalo je još jedino da plan potvrdi i Ministarski savet, posle čega su zemunske vlasti mogle punim intenzitetom da počnu s izgradnjom na prostoru leve obale Save. Vesti o tome pojavile su se uskoro i u dnevnoj štampi, uz optimistička predviđanja da bi već sledeće godine mogli da krenu prvi građevinski radovi. ${ }^{87}$

U iščekivanju rešenja Ministarskog saveta, došlo je do ukidanja Zemuna kao zasebne gradske opštine. Odlukom beogradske uprave Zemun je, zajedno sa bežanijskom i 12 drugih opština, uključen u sastav prestonice marta $1934 .{ }^{88}$ Ovo teritorijalno proširenje trebalo je da bude prvi korak ka

inv. br. 275, fasc. 620 , Zapisnik konferencije u predmetu regulacije inundacionog terena Opštine zemunske i bežanijske, 27. jun 1933.

${ }^{84}$ Beogradska opština je protivna izgrađivanju leve obale Save, Vreme, 5. april 1933.

${ }^{85}$ IAB, SO Zemun, inv. br. 256, fasc. 574, Zapisnik II redovne skupštine zastupstva grada Zemuna, 5. april 1933.

${ }^{86}$ IAB, SO Zemun, inv. br. 275, fasc. 620 , Zapisnik konferencije u predmetu regulacije inundacionog terena Opštine zemunske i bežanijske, 27. jun 1933.

${ }^{87}$ Ministar građevina je odobrio regulacioni plan inundacionog terena, Vreme, 23. jul 1933.

${ }^{88}$ Atar Beograda tada je proširen na opštine: Zemun, Bežanija, Višnjica, Mirijevo, Mali Mokri Lug, Veliki Mokri Lug, Kumodraž, Jajince, Resnik, Kneževac, Žarkovo, Železnik, Ovča i Borča. Područja na levim obalama Save i Dunava prvi put su tada uključena u teritorijalni sastav prestonice. Neposrednu vezu trebalo je da omoguće mostovi kralja Aleksandra I i kralja Petra II (tzv. „Pančevački“ most), koji u tom trenutku još nisu bili završeni - prvi je počeo rad u decembru 1934, a drugi u novembru 1935. Odluka o proširenju Beograda pokazala se uskoro brzopletom, pa je u aprilu 1935. revidirana. Iz sastava prestonice izdvojene su sve nove opštine, sem Zemuna i nekih delova Bežanije i Borče; videti Ranka Gašić, Problemi teritorijalnog širenja Beograda između dva svetska rata, Istorija 20. veka, br. 3, 2010, 65-66. 
neposrednom formiranju „Velikog Beograda“, kao i mera sprečavanja masovne bespravne gradnje $\mathrm{u}$ prigradskim zonama. ${ }^{89}$ Indirektno, time su onemogućene i sve pretenzije Zemuna u vezi s područjem budućeg Novog Beograda, a proces verifikacije plana Kovaljevskog je obustavljen. ${ }^{90}$ Prostor leve obale Save dospeo je u nadležnost beogradskih vlasti, koje u narednom periodu preuzimaju poslove oko njegovog uređivanja i izgradnje. To bi, ujedno, mogli da označimo i kao završetak „zemunske“ i početak „beogradske" faze u razvoju međuratnih planova za urbanu transformaciju tog područja. ${ }^{91}$

Imajući u vidu izloženi istorijski pregled, možemo da konstatujemo da su planovi za izgradnju na prostoru kasnijeg Novog Beograda bili, u manjem ili većem teritorijalnom obimu, kontinuirano prisutni u zemunskoj upravi od nastanka jugoslovenske države do 1934. godine, kada Zemun prestaje da postoji kao zaseban grad. Njihovo poreklo seže iz austrougarskog vremena, kada nastaje inicijalna ideja o formiranju industrijske zone na delu područja kasnijeg Novog Beograda koji se nalazio pod nadležnošću zemunske opštine. Ta ideja ostaje prisutna u zemunskoj upravi i po završetku Prvog svetskog rata, a tokom dvadesetih godina gradske vlasti čine i određene pokušaje u cilju njene realizacije. Međutim, s početkom izrade mosta kralja Aleksandra i puta Beograd-Zemun (1930), dolazi do nagle i radikalne transformacije te ideje koja se menja u projekat izgradnje pretežno stambenog naselja, na velikom delu područja kasnijeg Novog Beograda. Zbog novog projekta, koji je gradu trebalo da obezbedi veliku finansijsku dobit kroz prodaju građevinskih placeva, zemunske vlasti dolaze u sukob sa beogradskom upravom, koja je takođe bila zainteresovana za to zemljište. Konačno, integracija Zemuna u sastav Beograda indirektno je označila ne samo kraj tog sukoba, već i kraj svih daljih planova zemunske uprave $\mathrm{u}$ vezi sa područjem kasnijeg Novog Beograda. U skladu s činjenicom da su ti planovi generalno imali minimalan učinak u pogledu materijalne izgradnje, možemo da zaključimo da je njihov značaj prvenstveno bio idejni i ogledao se u afirmaciji urbanog razvoja tog prostora u međuratnom periodu.

${ }^{89}$ D. Vuksanović-Anić, Urbanistički razvitak Beograda u periodu između dva svetska rata (1919-1941), Istorija XX veka, Zbornik radova, IX, Beograd, 495-496.

${ }_{90}$ Beogradska uprava je tokom 1935. nameravala da plan Kovaljevskog upotrebi za uređenje leve obale Save, ali se kasnije od toga odustalo jer je odlučeno da se napravi nov projekat; videti: IAB, SO Zemun, inv. br. 256, fasc. 574, Dopis Ministarstva građevina - Poglavarstvu grada Beograda (Tehnička direkcija), 26. jun 1935.

${ }^{91}$ Za početak „zemunske faze" može se uzeti 1931. godina, kada je zemunska skupština usvojila smernice za izradu regulacionog plana za područje leve obale Save. 
Goran Antonić

\section{TERITTORY OF NEW BELGRADE IN INTER-WAR PLANS FOR URBAN DEVELOPMENT OF ZEMUN 1918-1934}

\section{Summary}

This paper deals with the inter-war plans for the expansion of Zemun on the left bank of the river Sava, where New Belgrade was later built. It examines the origins of these plans, which date back to the AustroHungarian times, and the course of their development, until the liquidation of the independence of the Zemun municipality and its integration into the structure of Belgrade in 1934. The importance of this topic in particular indicates the fact that the administration of Zemun was created not only the oldest previously known concept of regulation left bank of the river Sava, but that the government in 1932 made only regulation plan that was an official proposal for the construction of the urban structure on this area in the inter-war period. 